\title{
Melting of Northern Greenland during the last interglaciation
}

\author{
A. Born ${ }^{1,2}$ and K. H. Nisancioglu ${ }^{3,4}$ \\ ${ }^{1}$ Climate and Environmental Physics, Physics Institute, University of Bern, Bern, Switzerland \\ ${ }^{2}$ Oeschger Centre for Climate Change Research, Bern, Switzerland \\ ${ }^{3}$ Bjerknes Centre for Climate Research, University of Bergen, Bergen, Norway \\ ${ }^{4}$ UNI Research, Bergen, Norway
}

Correspondence to: A. Born (born@climate.unibe.ch)

Received: 21 November 2011 - Published in The Cryosphere Discuss.: 21 December 2011

Revised: 2 October 2012 - Accepted: 10 October 2012 - Published: 5 November 2012

\begin{abstract}
Using simulated climate data from the comprehensive coupled climate model IPSL CM4, we simulate the Greenland ice sheet (GrIS) during the Eemian interglaciation with the three-dimensional ice sheet model SICOPOLIS. The Eemian is a period $126000 \mathrm{yr}$ before present $(126 \mathrm{ka})$ with Arctic temperatures comparable to projections for the end of this century. In our simulation, the northeastern part of the GrIS is unstable and retreats significantly, despite moderate melt rates. This result is found to be robust to perturbations within a wide parameter space of key parameters of the ice sheet model, the choice of initial ice temperature, and has been reproduced with climate forcing from a second coupled climate model, the CCSM3. It is shown that the northeast GrIS is the most vulnerable. Even a small increase in melt removes many years of ice accumulation, giving a large mass imbalance and triggering the strong ice-elevation feedback. Unlike the south and west, melting in the northeast is not compensated by high accumulation. The analogy with modern warming suggests that in coming decades, positive feedbacks could increase the rate of mass loss of the northeastern GrIS, exceeding the recent observed thinning rates in the south.
\end{abstract}

\section{Introduction}

Recent observations show that ice loss on Greenland is accelerating (Velicogna, 2009; van den Broeke et al., 2009), contributing considerably to the rise in eustatic sea level (Rignot et al., 2011). However, there is no justification to extrapolate recent changes of the GrIS to long-term trends (Oerlemans et al., 2006). About half of its current mass loss is due to dynamic adjustments (van den Broeke et al., 2009), related to retreating calving fronts of tidewater glaciers (Pritchard et al., 2009). These processes can not sustain their present rate of retreat for very long, and concern relatively limited volumes of ice. On the other hand, recently observed large and highly variable melt areas (Bhattacharya et al., 2009) probably eclipse smaller, but sustained trends that are capable of causing a substantial sea-level rise in the long-term. Melt alone is a questionable indicator for ice sheet stability, because moderate melting may have a large effect in regions with low accumulation and weak ice transport. In this regard, the dry northeastern sector of the GrIS might be a very vulnerable region of the ice sheet (Fig. 1).

Studies of the geological past provide valuable information on the long-term response of the GrIS to warm periods. The last interglacial period, the Eemian, is considered the warmest period of the past 150 thousand years (Jansen et al., 2007). Evidence from fossil coral reefs suggest a sea-level highstand of 4 to $8 \mathrm{~m}$ (Overpeck et al., 2006; Kopp et al., 2009), mostly due to melting polar ice sheets while thermal expansion of ocean waters played a secondary role (McKay et al., 2011). Temperatures on and around Greenland were $0-5{ }^{\circ} \mathrm{C}$ higher than today (Axford et al., 2011; CAPE members, 2006; Otto-Bliesner et al., 2006). The warming and ice loss were caused by a change in seasonal insolation (van de Berg et al., 2011; Loutre et al., 2004), while greenhouse gas concentrations were comparable to preindustrial values (Petit et al., 1999; Lüthi et al., 2008). Nevertheless, the reconstructed warming of the Arctic during the Eemian is similar to the projected $2.8-7.8^{\circ} \mathrm{C}$ temperature increase for the end of this century (IPCC, 2007; Christensen et al., 2007; Clark and Huybers, 2009). 


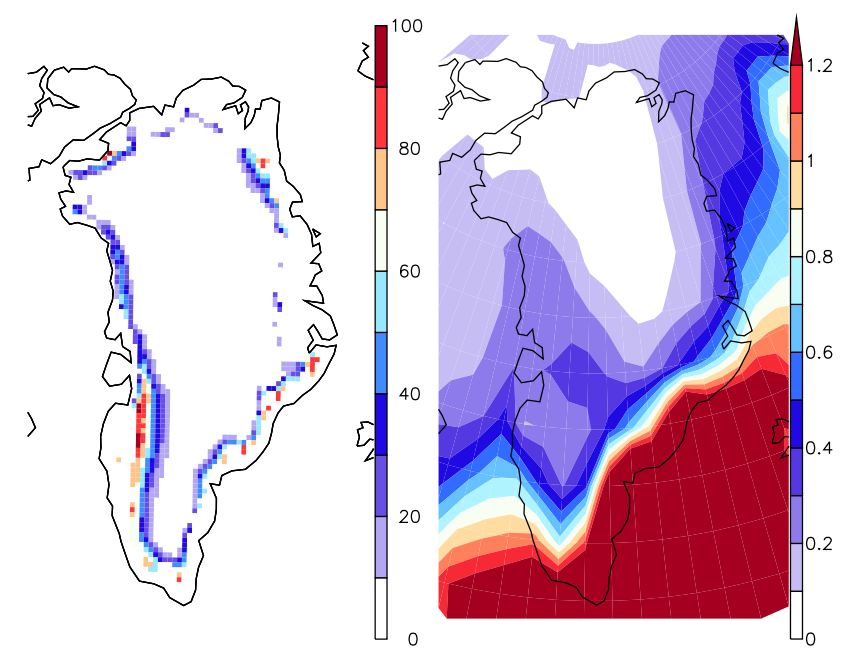

Fig. 1. Observed average duration of melt season in 1979-2007 (left, in days) (Abdalati, 2007), and average winter (DJF) precipitation in 1958-2001 from ERA-40 (right, in $\mathrm{myr}^{-1}$ ). As in the south, the northeastern region of the ice sheet shows a long melt season. Unlike regions in the south, however, the northeast receives very little precipitation to balance the melting.

Eemian sea-level estimates provide little constraint on the size of the GrIS, ranging from partial melting to a total loss of $7 \mathrm{~m}$ sea-level equivalent. The highest estimates of Eemian sea level include a potentially large but unknown contribution from the Antarctic ice sheet. Due to the expansion of ice at the last glacial maximum and the erosion of potential archives, few reliable proxy data exist for Eemian ice extent except for the Greenland ice cores. The bottom sections of the summit cores (GISP2, GRIP, NGRIP) and the northwestern core at Camp Century contain Eemian ice (Dansgaard et al., 1985; Chappellaz et al., 1997; NGRIP-members, 2004; Landais et al., 2004; Suwa et al., 2006), indicating that the GrIS covered these locations. Tentative results from the NEEM also suggest the existence of Eemian ice (Foresta, 2011). The isolated ice cap on the Renland peninsula also contains ice in its bottom section, dated to be older than $130 \mathrm{ka}$ (Johnsen et al., 1992). In southeastern Greenland, at the Dye-3 core site, basal ice is also found to predate the Eemian (Willerslev et al., 2007). However, due to its very old age ( $>400000 \mathrm{yr})$ and the lack of direct evidence of Eemian ice, an Eemian glaciation at this site remains uncertain (Alley et al., 2010). A recent study concluded moderate melting of the southern GrIS, supporting the persistence of the southern dome and probably Dye-3 (Colville et al., 2011). Two isolated ice caps in northern and northeastern Greenland (Hans Tausen Iskappe and Flade Isblink) do not hold ice older than the thermal optimum of the present interglaciation (Hammer et al., 2001; Lemark, 2010).

Previous model studies of the last interglaciation found substantial melting of the southern part of the Greenland ice sheet, equivalent to a global sea- level rise of $4-5.5 \mathrm{~m}$
(Cuffey and Marshall, 2000) or 2-3 m (Otto-Bliesner et al., 2006). The low estimate requires melting of the southern dome of the GrIS, whereas the high estimate requires additional melting of the northernmost part of the GrIS. Several studies describe a melting of the northern GrIS with Eemian boundary conditions, either in addition to a near complete loss of the South Dome (Huybrechts, 2002; Tarasov and Peltier, 2003; Lhomme et al., 2005), or with significant melting in the north while no ice is lost in the south (Fyke et al., 2011). Sea-level rise estimates of these studies range from 2 to $5.5 \mathrm{~m}$. Yet another scenario is offered by Robinson et al. (2011) who simulate melting from the west and north that separates the southernmost part of the GrIS, resulting in a sea- level rise of $0.4-4.4 \mathrm{~m}$. All of these studies explain a substantial part of the reconstructed sea-level highstand of the last interglacial period, but most contradict the evidence for Eemian ice at the core locations discussed above.

We simulate the GrIS at $126 \mathrm{ka}$, using a three-dimensional ice sheet model, forced with a climate simulation from a comprehensive coupled climate model. We describe a high sensitivity to Eemian boundary conditions and strong melting in the northeastern GrIS. The robustness of this result is validated with a large ensemble of sensitivity simulations and theoretical considerations of ice sheet stability. This paper is organized as follows. The ice sheet and climate models are described in Sect. 2. Sect. 3 presents results of the analysis, divided into the simulation of the GrIS (Sect. 3.2), quantification of ice sheet stability (Sect. 3.3) and the presentation of ensemble simulations (Sect. 3.4). Section 4 discusses the results. We summarize and conclude in Sect. 5

\section{Model description}

We use the three-dimensional, thermomechanical ice sheet model, SICOPOLIS 2.9 (Greve, 1997), forced with monthly temperature and total precipitation from the Institut Pierre Simon Laplace Coupled Model 4 (IPSL CM4) (Marti et al., 2005). The horizontal resolution of the ice sheet model is $10 \mathrm{~km}$ with 90 vertical layers. The lower 10 layers simulate ice at the pressure melting point. Ice dynamics are represented with the shallow-ice approximation, neglecting longitudinal stresses. This simplification is valid for ice masses that are thin compared to their lateral extent, flowing slowly over a horizontal bed. Ice shelves can not be simulated, nor can valley glaciers. This is a widely used approximation that yields satisfactory results for the predominantly cold-based Greenland ice sheet on a flat topography.

Geothermal heat flux has a non-uniform distribution (Pollack et al., 1993), ice and bedrock topographies are initialized with modern observations (Amante and Eakins, 2009), and the bedrock responds to ice load with a relaxation time of $3000 \mathrm{yr}$. The initial temperature of the ice is constant at $-50^{\circ} \mathrm{C}$ in the upper part of the ice sheet, increasing linearly to $-5^{\circ} \mathrm{C}$ at the bedrock over the lower $1000 \mathrm{~m}$ of ice. This 
temperature profile qualitatively matches modern bore hole temperatures at the GRIP ice core (Johnsen et al., 1995). $-50^{\circ} \mathrm{C}$ corresponds to the temperature of ice that accumulated at this same location during the last glaciation (DahlJensen et al., 1998). To test the sensitivity to the choice of initial conditions, additional experiments were carried out with ice temperatures of $-30^{\circ} \mathrm{C}$, approximating the present-day ice profile, and $-40^{\circ} \mathrm{C}$.

Climate forcing is provided from simulations of the coupled model IPSL CM4. Three climate model experiments are used as boundary conditions for the ice model: Eemian (126 ka), glacial inception (115 ka) and preindustrial (1850 AD, $0 \mathrm{ka})$. All employ constant present-day ice topography, surface conditions and preindustrial greenhouse gas concentrations. For the Eemian and glacial inception, orbital parameters are adjusted to their values at $126 \mathrm{ka}$ and $115 \mathrm{ka}$, respectively. While this set-up generally is a good approximation for the Eemian, the use of present-day topography is probably not realistic for the GrIS. However, the simulation compares well with existing proxy data, also in the vicinity of the GrIS (Braconnot et al., 2008; Born et al., 2010, 2011).

A second set of forcing fields is obtained from the Community Climate System Model 3 (CCSM3) for the Eemian at $130 \mathrm{ka}$, in order to test the robustness of the results to the choice of climate model. The experimental design is equivalent to IPSL CM4. An extensive discussion of this experiment can be found in Otto-Bliesner et al. (2006).

Climate fields are interpolated bilinearly to match the horizontal resolution of the ice sheet model. In addition, temperature fields are corrected for the coarse representation of the surface height of the GrIS in IPSL CM4 and CCSM3, and by following the evolving ice topography in SICOPOLIS, using a fixed atmospheric lapse rate of $-6.5^{\circ} \mathrm{C} \mathrm{km}^{-1}$. This corrected monthly temperature is used to calculate melt according to the positive degree day method (Reeh, 1991). Accumulation, i.e. solid precipitation, is estimated using interpolated monthly fields for temperature and total precipitation. The total precipitation from the climate model is interpreted as $100 \%$ snow if the monthly average temperature is lower than, or equal to $-12^{\circ} \mathrm{C}$. Similarly, above $+4{ }^{\circ} \mathrm{C}$, all precipitation is given as rain and does not contribute to the mass balance. A linear interpolation is employed between these two temperatures. The interpolation procedure for CCSM3 is identical to IPSL CM4.

\section{Results}

\subsection{Simulated greenland climate}

The interpolated and elevation-corrected summer temperatures from the preindustrial experiment with IPSL CM4 (Fig. 2a) agree well with observations (Steffen and Box, 2001). For the Eemian (Fig. 2b), summer temperatures are on average $3.2^{\circ} \mathrm{C}$ higher compared to present-day, with stronger warming at high latitudes and elevations (Fig. 3). This anomaly is consistent with changes in (summer) insolation forcing, which increase toward high latitudes and have an enhanced effect at high altitudes where the cloud cover is less persistent. Simulated winter precipitation (Fig. 2c) also generally agrees with observations (Fig. 1, right), but is too high in the north and west. Changes in precipitation at $126 \mathrm{ka}$ are minor in IPSL CM4 (Fig. 2d).

In the CCSM3, preindustrial near surface summer temperatures are higher than in IPSL CM4 (Fig. 4a). In this model, Eemian summer climate is approximately $4.1{ }^{\circ} \mathrm{C}$ warmer than preindustrial. However, the temparature anomaly pattern is similar to that of the IPSL CM4 (not shown). The simulated precipitation of CCSM3 does not match observations very well (Fig. 4c). Southern and eastern Greenland receive too little precipitation while the north is too wet. The precipitation distribution changes considerably with $130 \mathrm{ka}$ boundary conditions (Fig. 4d).

\subsection{Simulated Greenland ice sheet cover}

Running the ice sheet model for $10000 \mathrm{yr}$ with preindustrial climate forcing ( $0 \mathrm{ka})$ from IPSL CM4, initialized with cold ice, yields a fully glaciated Greenland (Fig. 5a). Compared to the modern observed ice topography, the ice is slightly too thick and its area too large.

When simulating the GrIS at the Eemian, the time evolution of the ice sheet is critical. In particular, the duration of melting on Greenland during the Eemian is not wellconstrained by proxy data (e.g. Yokoyama and Esat, 2011). To estimate this duration, a transient simulation with the SICOPOLIS GrIS model is carried out spanning the period $130 \mathrm{ka}$ to $110 \mathrm{ka}$, forced with two time-slice simulations of IPSL CM4 at $126 \mathrm{ka}$ and $115 \mathrm{ka}$. After interpolating the climate model data spatially as described in Sect. 2, transient forcing was obtained by a temporal interpolation of the two climate model time-slice simulations over a $20000 \mathrm{yr}$ period from $130 \mathrm{ka}$ to $110 \mathrm{ka}$, using June insolation at $65^{\circ} \mathrm{N}$ as a normalized scalar index (Fig. 6a). Linear interpolation has not been used because it yields unrealistic results for the extrapolation before $126 \mathrm{ka}$ and after $115 \mathrm{ka}$.

Due to insufficient proxy data, the ice sheet is initialized with present-day ice and bedrock topographies at $130 \mathrm{ka}$. It is unclear whether this is a good starting point, or if the present-day shape of the ice sheet is a good approximation for that period. From this simulation, the duration of melting is estimated to approximately $6000 \mathrm{yr}$ (Fig. 6). After that, ice re-grows due to the falling solar insolation, the last glacial inception. However, this approach has several caveats. The interpolated seasonal climate forcing of the transient experiment is only an approximation and not an accurate representation of Eemian climate evolution. Conceivable abrupt climate shifts during the penultimate deglaciation are disregarded as are changes in climate due to the shrinking ice sheet. In summary, the transient simulation is not considered 


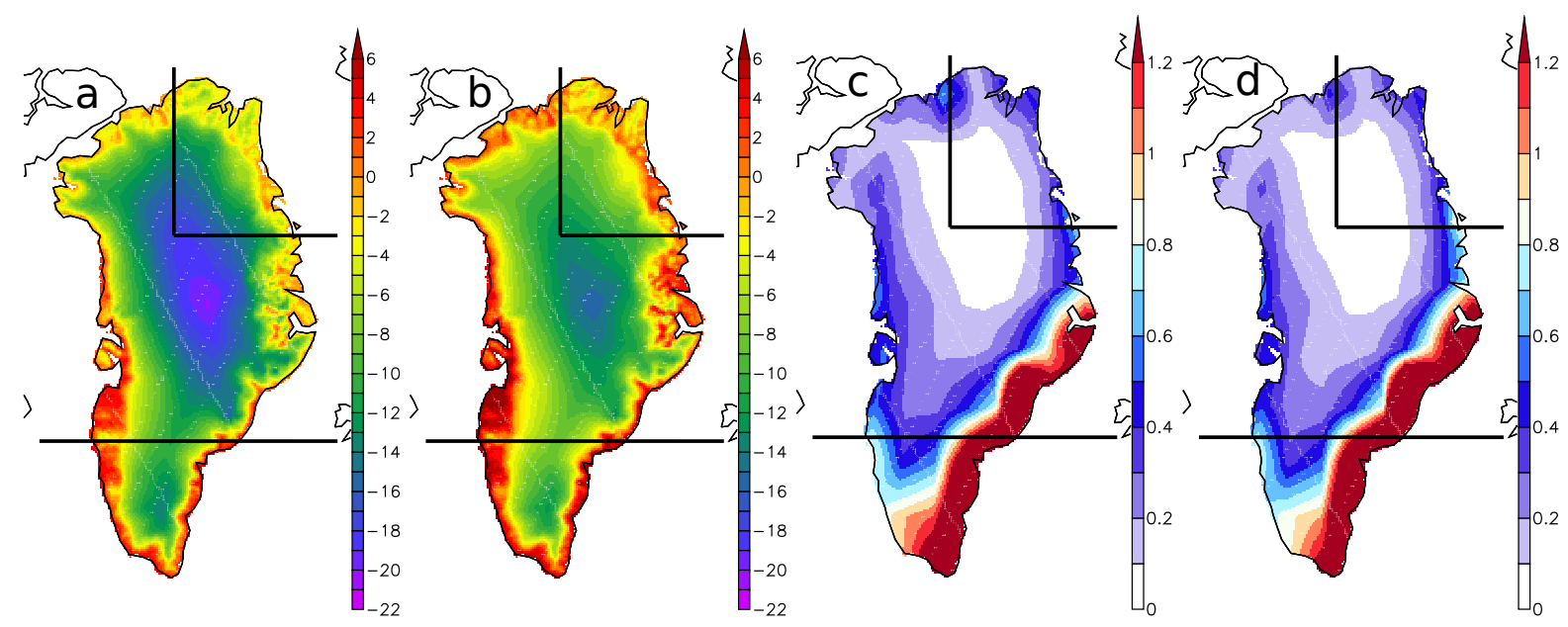

Fig. 2. Seasonal averages of forcing fields from IPSL CM4, interpolated onto the ice sheet model grid. Temperature data has been corrected with a fixed lapse rate of $-6.5^{\circ} \mathrm{C} \mathrm{km}^{-1}$ to adjust for height differences between ice sheet and climate model. (a) Summer (JJA) surface temperature for preindustrial climate $\left(0 \mathrm{ka}\right.$, in $\left.{ }^{\circ} \mathrm{C}\right)$, (b) JJA surface temperature for $126 \mathrm{ka}\left(\right.$ in $\left.{ }^{\circ} \mathrm{C}\right)$, (c) Winter (DJF) precipitation for $0 \mathrm{ka}$ (in

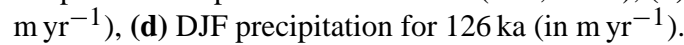

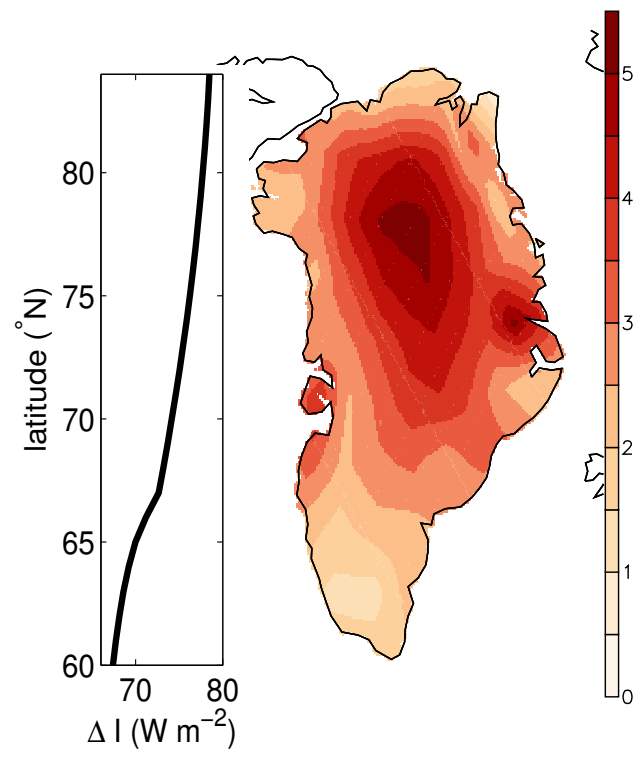

Fig. 3. Difference $126 \mathrm{ka}-0 \mathrm{ka}$ in summer insolation (left) and JJA surface air temperature in IPSL CM4 (in ${ }^{\circ} \mathrm{C}$, right).

more realistic than a simulation with invariable climate forcing, and its results are solely used to constrain the melt duration.

A new simulation with climate forcing fixed to $126 \mathrm{ka}$ values is used to investigate the response of the GrIS. After $6000 \mathrm{yr}$, the loss of Greenland ice corresponds to a global sea-level rise of $4.2 \mathrm{~m}$ (Fig. 5b). Large regions become icefree, most notably in the northeast and southwest. The locations of all deep ice core sites remain glaciated. Within the $10000 \mathrm{yr}$ duration of the simulation with constant forcing, the only long ice core to become ice-free is NEEM. This occurs after 8300 model years, and defines an upper limit for sea-level rise of $5.9 \mathrm{~m}$. Ice at Dye- 3 becomes thinner, but does not disappear until the end of the $10000 \mathrm{yr}$ simulation.

Melting of the ice margins results in reduced ice thickness in the remaining ice sheet (Fig. 5, right). After $6000 \mathrm{yr}$, ice at the location of today's Greenland summit is about $400 \mathrm{~m}$ thinner in the Eemian than in the modern simulation, which compares well to estimates based on total gas content at GRIP (Raynaud et al., 1997; Cuffey and Marshall, 2000) and $\delta^{18} \mathrm{O}$ (Masson-Delmotte et al., 2011). Thinning at NGRIP is simulated to be less than $200 \mathrm{~m}$, in agreement with a negligible reduction in elevation found for the late Eemian at this site (Svensson et al., 2011). NEEM experiences a thinning of approximately $300 \mathrm{~m}$, Dye- 3 of $100 \mathrm{~m}$ and a slight thickening is simulated at Camp Century.

\subsection{Changes in surface mass balance and ice stability}

In order to investigate the impact of Eemian climate on the GrIS mass balance, independent of feedback mechanisms arising from changes in ice topography and flow, we compare the simulated mass balance for the Eemian (126 ka) and preindustrial climate $(0 \mathrm{ka})$ for the first time step after model initialization, i.e. before changes in ice topography take place. Eemian warming results in increased melt everywhere (Fig. 7, left). However, only moderate melt is seen in northeastern Greenland, with higher melt simulated further south. Accumulation of snow is reduced in the south and west of the ice sheet due to higher temperatures. Also as a result of higher atmospheric temperatures and vapor content, especially at higher altitudes, accumulation slightly increases in central and northeastern Greenland. However, in 


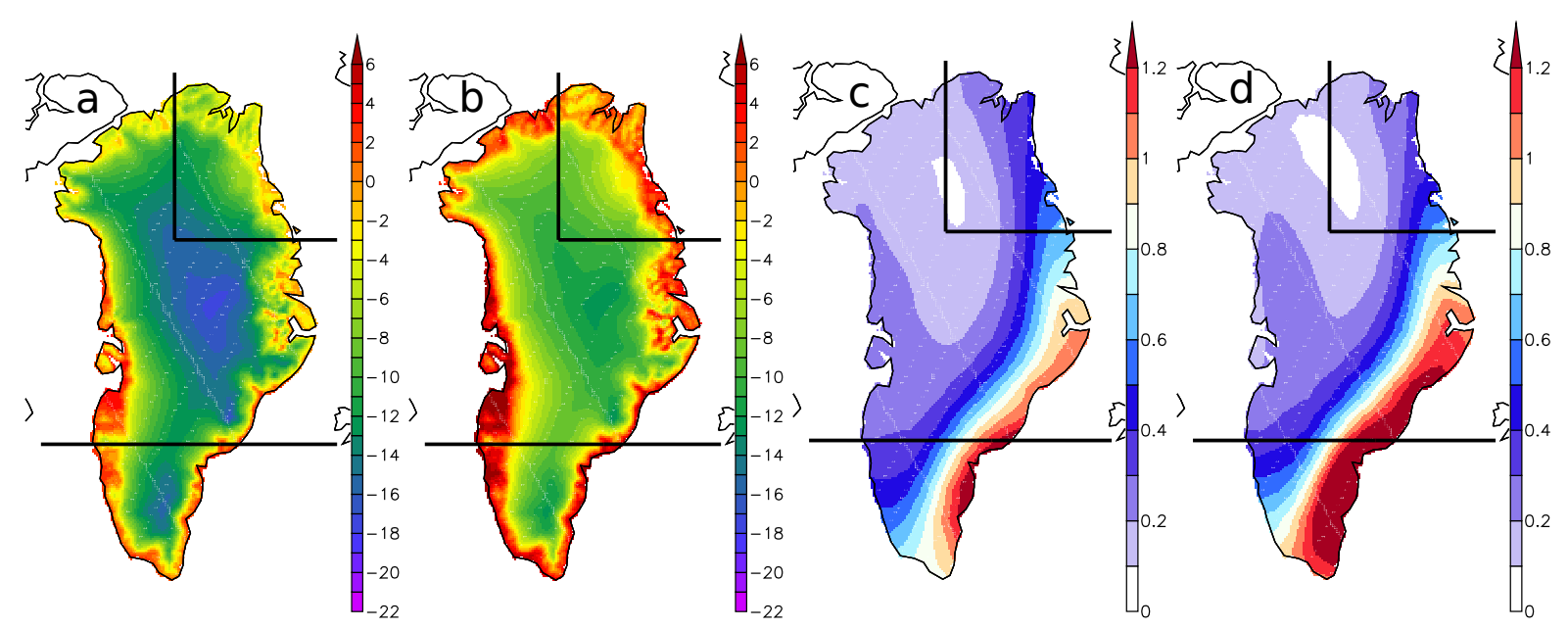

Fig. 4. As Fig. 2, but for CCSM3.

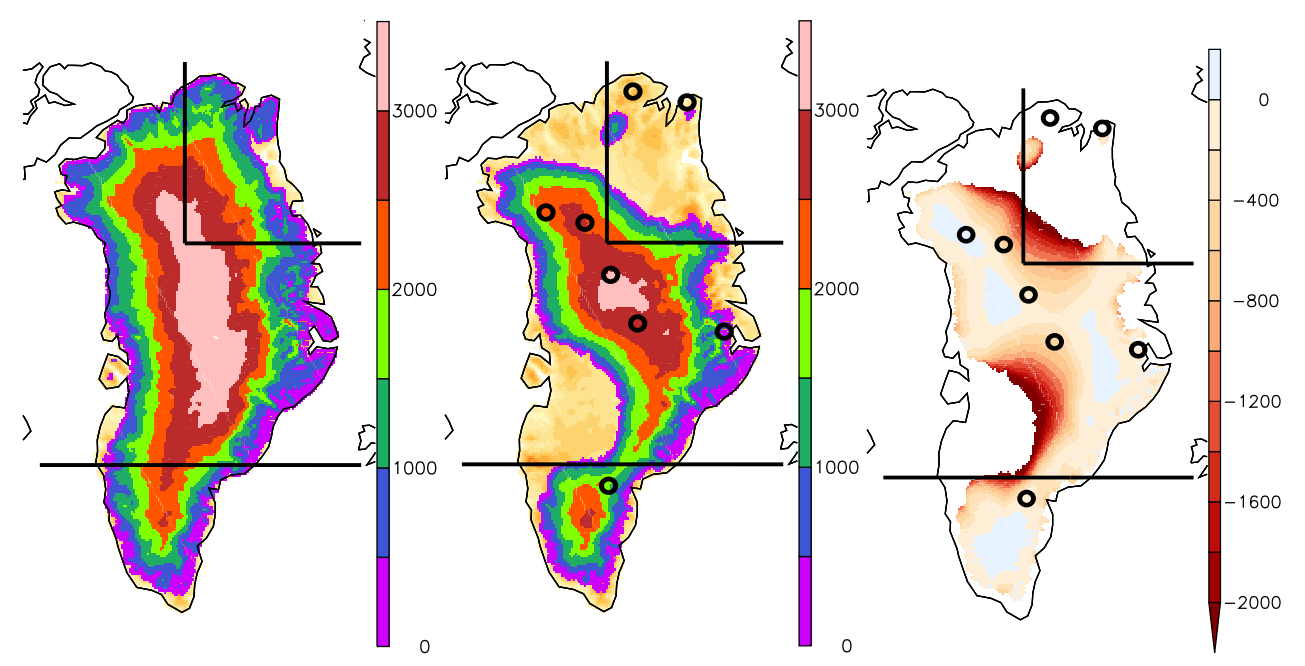

Fig. 5. Modelled ice thickness (in $\mathrm{m}$ ) after $10000 \mathrm{yr}$ of simulation with preindustrial forcing (left) and after $6000 \mathrm{yr}$ with $126 \mathrm{ka}$ forcing (middle). Difference in ice thickness $126 \mathrm{ka}-0 \mathrm{ka}$ (right). Regions defined for this study are separated by bold black lines. Circles show locations of ice core sites (from north to south: Hans Tausen Iskappe, Flade Isblink, Camp Century, NEEM, NGRIP, GRIP, Renland, Dye-3). Preindustrial ice area and thickness are well reproduced. With $126 \mathrm{ka}$ forcing, the Greenland ice sheet melts mostly from the northeast and southwest. The southern dome does not disappear.

general, changes in accumulation are at least one order of magnitude smaller than in ablation and therefore negligible (Fig. 7, right).

Clearly changes in climate alone can not explain the rapid ice loss in northeastern Greenland, which must be aided by the positive ice-elevation feedback mechanism that dominates the rate of melting after an initial period. On the other hand, the feedback is only the reaction to the primary trigger, the change in climate. Thus, we would like to estimate the a priori unknown response of the feedback from readily available surface mass balance terms and thereby quantify the vulnerability of different regions of the GrIS to Eemian climate.
This requires two key assumptions to be made that are motivated by the design of the numerical experiments and our aim to construct the most elementary model to explain the numerical experiments: (1) firstly, changes in accumulation are small, which appears reasonable from the simulation with SICOPOLIS (Fig. 7, right). (2) Secondly, changes in ice flow are neglected. Since $0 \mathrm{ka}$ and $126 \mathrm{ka}$ simulations are initiated with the same modern ice and bedrock topographies, ice flow is the same in both experiments initially. This will change over the course of the simulation but we assume that lateral ice flow can not accelerate enough to compensate the fast vertical changes in ice elevation and is thus negligible. This assumption will be tested later on. 


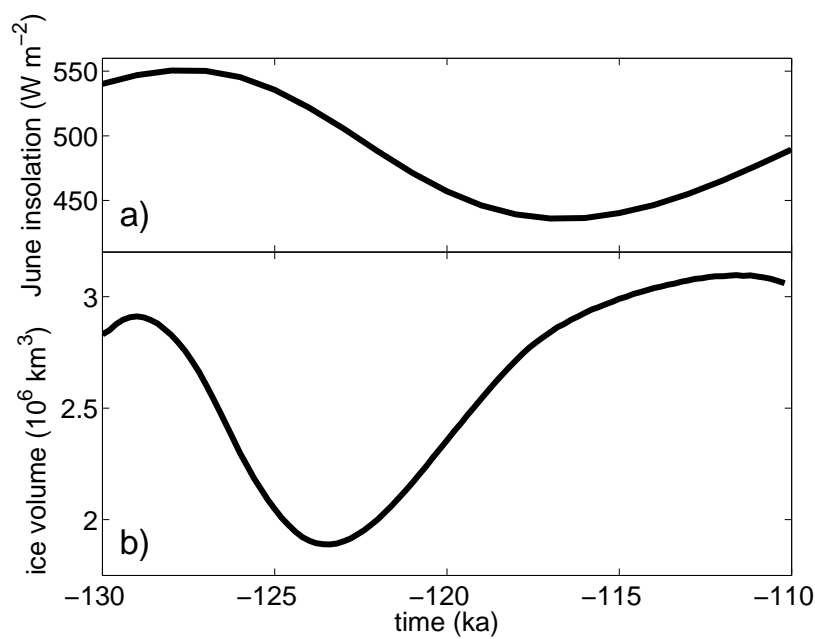

Fig. 6. (a) June insolation at $65^{\circ} \mathrm{N}$. (b) Average ice thickness evolution of the GrIS between $130 \mathrm{ka}$ and $110 \mathrm{ka}$. The model was initialized with preindustrial ice and bedrock topographies. Some adjustment is visible in the first $1000 \mathrm{yr}$. After that, ice melts for approximately $6000 \mathrm{yr}$, followed by a recovery at the end of the last interglaciation.

Neglecting lateral transport of ice, changes in ice elevation $H(t)$ only depend on the balance between accumulation $\mathrm{ACC}$ and ablation $\mathrm{ABL}(t)$, where ACC is approximately constant, and $H(t)$ and $\mathrm{ABL}(t)$ vary in time:

$\partial_{t} H(t)=\mathrm{ACC}-\operatorname{ABL}(t)$.

The positive ice-elevation feedback, manifested by increased melt as the ice surface reaches lower elevations, can be simplified as

$\operatorname{ABL}(t)=-\alpha\left(H(t)-H_{0}\right)$,

where $\alpha$ is a constant positive factor characterizing the elevation dependence of ablation and $H_{0}$ is the ice thickness where ablation becomes zero. For simplicity the feedback has been linearized here. Its nonlinearity is not relevant for the argument presented here. The time derivative yields

$$
\partial_{t} \operatorname{ABL}(t)=-\alpha \partial_{t} H(t)
$$

Combining Eqs. (1) and (3) yields:

$\partial_{t} \operatorname{ABL}(t)=\alpha(\operatorname{ABL}(t)-\operatorname{ACC})$,

dividing by accumulation:

$$
\begin{aligned}
\partial_{t}\left(\frac{\mathrm{ABL}(t)}{\mathrm{ACC}}\right) & =\frac{\partial_{t} \mathrm{ABL}(t)}{\mathrm{ACC}}=\alpha\left(\frac{\mathrm{ABL}}{\mathrm{ACC}}-1\right) \\
\Rightarrow \frac{\mathrm{ABL}}{\mathrm{ACC}}(t) & =e^{\alpha t}+1 .
\end{aligned}
$$

In equilibrium and without lateral ice transport, the ratio of melt to accumulation ABL/ACC must be one to hold ice

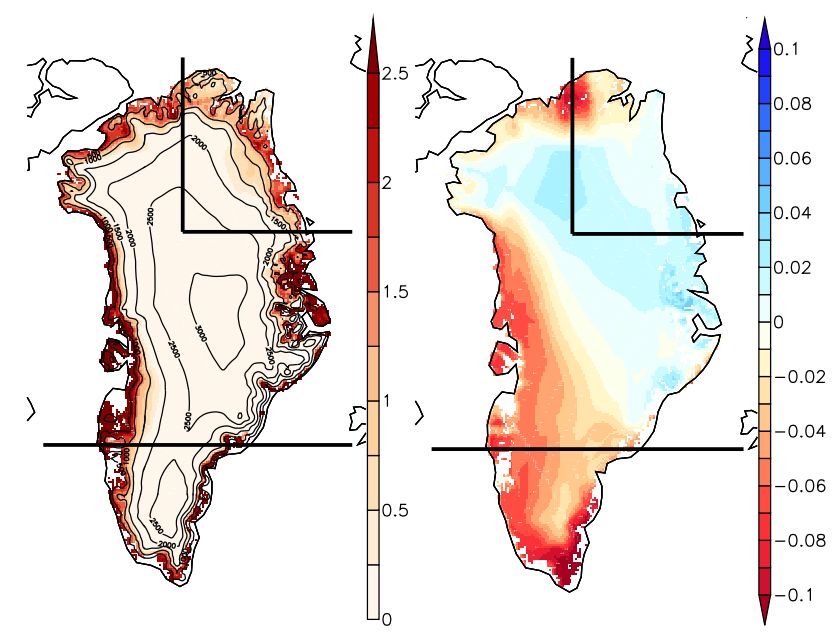

Fig. 7. Anomalies and ratios of change at the first model time step, thus independent from changes in ice topography and dynamics: (left) melt anomaly " $126 \mathrm{ka}-0 \mathrm{ka}$ " (color, $\mathrm{m} \mathrm{yr}^{-1}$ ) and initial ice elevation (contours, m). (Right) accumulation anomaly " $126 \mathrm{ka}-0 \mathrm{ka}$ " (color, $\mathrm{m} \mathrm{yr}^{-1}$ ). With 126 ka climate boundary conditions, melting increases throughout the entire ice sheet, mostly in low-lying regions and in large regions in northern Greenland. Accumulation changes are at least one order of magnitude smaller.

elevation invariant. Following Eq. (5), an imbalance in the $\mathrm{ABL} / \mathrm{ACC}$ ratio grows exponentially due to the ice-elevation feedback. This essentially reflects increased melting and thus ice loss while changes in accumulation are negligible (Fig. 7, right).

The absolute change in relative surface mass balance $\left(\mathrm{ABL}_{126 \mathrm{ka}}-\mathrm{ABL}_{0 \mathrm{ka}}\right) / \mathrm{ACC}_{0 \text { ka }}$ quantifies surplus ablation due to Eemian warmth in "accumulation-years". It therefore estimates how many years of average accumulation are lost by the additional melting, a measure of local ice sheet stability (Fig. 8, left). Regions of ice retreat are identified by high values, thus an unsustainable increase in melting. In particular, manifold imbalances reach far inland in the northeast due to the low accumulation (Figs. 1, 2c, d). In contrast to the southwest, this affects not only marginal ice areas but also ice that is dynamically connected to the large interior body of the ice sheet.

Note that the ratio ABL/ACC will always have values above one near the ice margin, even for an ice sheet in dynamical equilibrium because ice flow from interior regions compensates for ice loss at lower elevations. By how much would the ice flow have to increase to counteract the imbalance in surface mass balance due to Eemian climate? In steady state, changes in ice elevation due to accumulation $\mathrm{ACC}$, melting $\mathrm{ABL}$ and ice flow $F$ balance to zero:

$$
\begin{aligned}
\partial_{t} H & =\mathrm{ACC}-\mathrm{ABL}+F=0 \\
& \Rightarrow F=-(\mathrm{ACC}-\mathrm{ABL})=-(\text { absolute surface mass balance })
\end{aligned}
$$




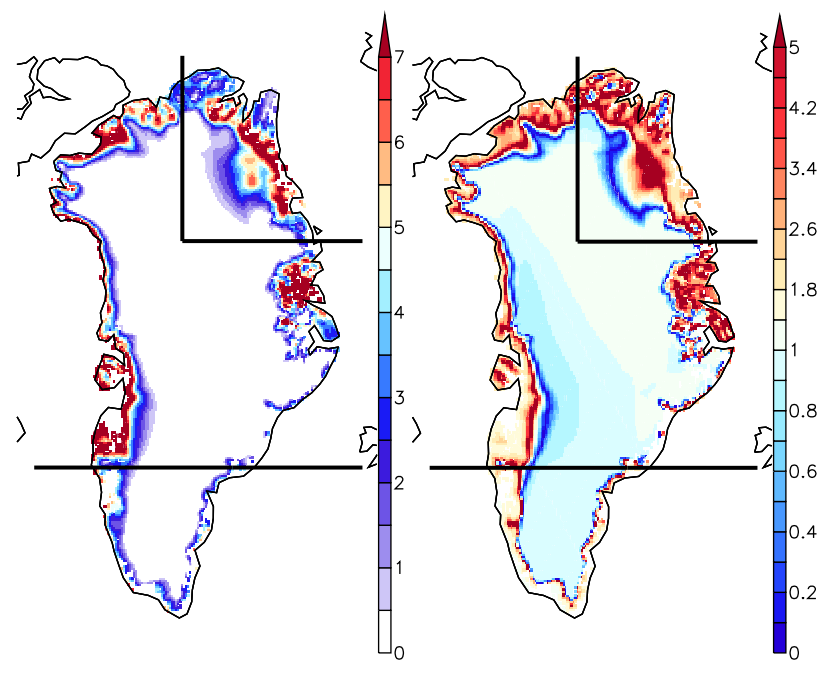

Fig. 8. (Left) Ratio between melt anomaly and preindustrial accumulation, $\left(\mathrm{ABL}_{126 \mathrm{ka}}-\mathrm{ABL}_{0 \mathrm{ka}}\right) / \mathrm{ACC}_{0 \mathrm{ka}}$. It quantifies surplus melting in "accumulation-years", a measure of instability. The northeastern region of Greenland is the least stable. (Right) Ratio of absolute surface mass balances, $(\mathrm{ACC}-\mathrm{ABL})_{126 \mathrm{ka}} /(\mathrm{ACC}-\mathrm{ABL})_{0 \mathrm{ka}}$. For mass flow to balance surface imbalances, it needs to increase by the same factor, which is unrealistically large for the northeastern GrIS.

Thus, relative changes in absolute surface mass balance, $(\mathrm{ACC}-\mathrm{ABL})_{126 \mathrm{ka}} /(\mathrm{ACC}-\mathrm{ABL})_{0 \mathrm{ka}}$, must be matched by equal changes in ice volume transport. Here again, the northeastern GrIS is identified as the least stable region with a required fivefold increase in ice flow (Fig. 8, right). Such an increase might be possible near steep topographic gradients but is unlikely for this relatively large region of smooth ice and bedrock topography. In contrast, the region of manifold surface mass balance in the southwest is a relatively thin band restricted to the margin. Steep surface slopes are already present and further enhanced by melting of the lowest elevation ice. This dynamical regime is different from the northeast and ice flow can effectively slow down ice loss. Moreover, the melting in the west causes the ice divide to move eastward and thereby draws more ice from the stable region to the southeast of the ice sheet which receives most accumulation. The simplification of negligible ice flow in Eq. (1) is thus justified for northeastern Greenland. Note also that in spite of this crude simplification, the above concept does describe the ice loss in the comprehensive threedimensional ice sheet model successfully.

\subsection{Ensemble simulations}

To assess the robustness of our results, a large ensemble of experiments was run covering a wide range of parameter space, extending the methodology of Ritz et al. (1997) (Table 1). Similar recent attempts include Robinson et al. (2011) and Applegate et al. (2011). Aside from the tested parameters, the experiments are configured and initialized as described in Sect. 2. In contrast to the experiments decribed above, heat flux is uniform in the ensemble experiments. All experiments have been run for $10000 \mathrm{yr}$ in order to reach quasi-equilibrium.

As the GrIS loses mass, thinning in the northeast is faster than in the south (Fig. 9, left), consistent with the transient evolution of the original experiment and corroborating the higher vulnerability of the northeastern region. This result is reproduced with climate forcing from the $130 \mathrm{ka}$ simulation with CCSM3 (Fig. 9, right). The coupling scheme for CCSM3 is identical to the description above, i.e. the interpolated climate fields are applied without modification.

\section{Discussion}

Previous model studies of the Eemian identified the southern GrIS as the most vulnerable (Cuffey and Marshall, 2000; Lhomme et al., 2005; Otto-Bliesner et al., 2006). Other simulations found additional melting of the northern GrIS (Huybrechts, 2002; Tarasov and Peltier, 2003; Robinson et al., 2011; Fyke et al., 2011). However, several of these studies describe a retreat of the ice edge from the north or northwest, which in many cases leads to ice-free conditions at Camp Century and NEEM, contradicting proxy data. This is not the case in the simulation presented in the present study, where Eemian ice at Camp Century and NEEM are preserved.

Climate forcing in these previous studies is very different from what is employed here, which might partly explain the different results. The older studies emulate past climates as a spatially homogeneous anomaly of today's temperature pattern, modulated by a single index based on proxy data, usually the GRIP $\delta^{18} \mathrm{O}$ record, quantifying temperature variations in time (Cuffey and Marshall, 2000; Huybrechts, 2002; Tarasov and Peltier, 2003; Lhomme et al., 2005). Since the same index is applied to the entire GrIS, this approach does not take into account different trends in different regions, nor does it capture changes in the pattern of atmospheric circulation and precipitation. However, more importantly, the preferential warming of northern Greenland during the Eemian due to larger insolation changes is not captured. More recent simulations employ regional energy-moisture balance models to downscale climate simulations of very coarse resolution and dynamically simplified climate models onto the ice sheet model grid in a physically consistent way (Robinson et al., 2011; Fyke et al., 2011). Interestingly, these studies find a more vulnerable northern GrIS. The coupling procedure used in Otto-Bliesner et al. (2006) makes use of the simulated climate from a comprehensive coupled climate model, similar to our approach. The main difference is that these authors forced their ice sheet model with the simulated climate anomaly for the Eemian ( $130 \mathrm{ka}-0 \mathrm{ka})$ added to the observed climatology, while we use the simulated climate fields directly. 
Table 1. Parameter range for ensemble experiments and standard values used in the simulations above. Heat flux is non-uniform in the standard experiment. One experiment for every possible permutation of the above parameters has been carried out, for two different climate forcings, giving a total of 15552 model simulations (see Fig. 9).

\begin{tabular}{llll}
\hline Parameter & Value & Standard value & Unit \\
\hline Initial ice temperature & $-50 \ldots 10 \ldots-30$ & -50 & ${ }^{\circ} \mathrm{C}$ \\
Geothermal heat flux & $30 \ldots 10 \ldots 80$ & $\sim 65$ & $\mathrm{~m} \mathrm{~W} \mathrm{~m}^{-2}$ \\
Degree-day factor for snow & $3 \ldots 8$ & 5 & $\mathrm{~mm} \mathrm{day}^{-1} \mathrm{~K}^{-1}$ \\
Degree-day factor for ice & $10 \ldots 2 \ldots 20$ & 14 & $\mathrm{~mm} \mathrm{day}^{-1} \mathrm{~K}^{-1}$ \\
Basal sliding & $5 \ldots 2 \ldots 15$ & 11.2 & $\mathrm{~m} \mathrm{a}^{-1} \mathrm{~Pa}^{-1}$ \\
Flow enhancement factor & 1,3 & 3 & dimensionless \\
\hline
\end{tabular}

Biases of the simulated climate, especially at high northern latitudes and at high elevations of the Greenland ice sheet, are potentially large and might explain some discrepancies between different studies (Masson-Delmotte et al., 2010). The main finding of the present study, however, is unlikely to result from model biases. The results have been reproduced with climate forcing of a second comprehensive climate model. Both climate models have been validated to simulate Eemian climate consistent with proxy data in previous studies (Overpeck et al., 2006; Otto-Bliesner et al., 2006; Braconnot et al., 2008; Born et al., 2010, 2011). The impact of contingent climate biases is effectively simulated by changing the melt parameters of the ice sheet model, which was found to not change the high vulnerability of the northeastern GrIS. Similarly, the wide range of parameters changing the ice sheet dynamics makes a dependence on the choice of ice sheet model unlikely as well. Uncertainty remains in the choice of initial conditions, which were derived from the present-day ice and bedrock topography and a piecewise linear approximation of present-day borehole temperatures. This configuration might result in inconsistent dynamics and thermodynamics within the initial ice sheet and subsequent experiments might be affected by a relaxation to model equilibrium. Nevertheless, this initialization method enables us to test this uncertainty with different initial temperatures and the results are found to be robust.

Currently available proxy data is inconclusive as to the shape of the Eemian GrIS. Pollen in marine sediments off the south Greenland coast has been interpreted to imply considerable melting of the GrIS to allow for growth of extensive vegetation (de Vernal and Hillaire-Marcel, 2008). Considerable melting of the GrIS in the south is supported by the finding of a greater discharge of glacial flour during the Eemian than during the early Holocene (Carlson et al., 2008). However, isotopic analysis of the glacial flour off Greenland has recently been found to source from all 3 south Greenland Precambrian terranes and thus significant ice remained on southern Greenland through the Eemian (Colville et al., 2011). An early analysis of basal ice from Dye-3 concluded that ice at this location disappeared during the Eemian, as well as at Camp Century (Koerner, 1989). However, several
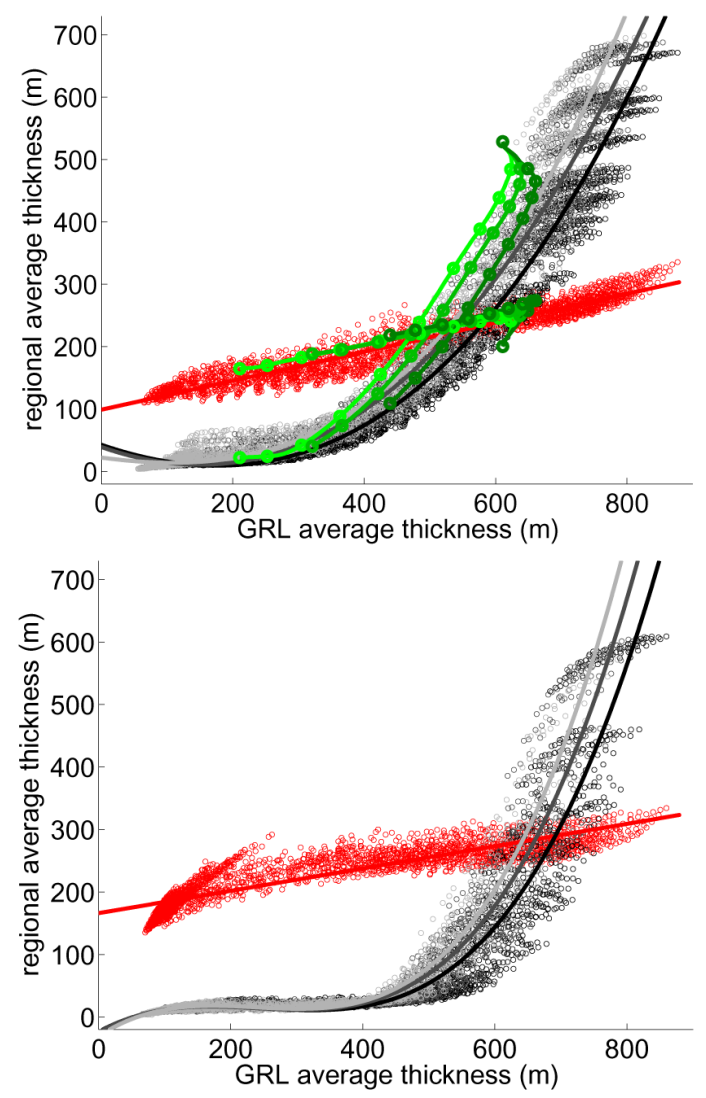

Fig. 9. Simulated average ice thickness in northeastern (gray, black) and and southern (red) regions, as a function of the average ice thickness of the entire ice sheet, for $126 \mathrm{ka}$ in IPSL CM4 (top panel) and $130 \mathrm{ka}$ in CCSM3 (bottom panel). Each data point corresponds to one of 15552 ensemble members with a different set of parameters, run for $10000 \mathrm{yr}$. Different ice initial temperatures are highlighted for northeastern Greenland in light gray $\left(-30^{\circ} \mathrm{C}\right)$, gray $\left(-40^{\circ} \mathrm{C}\right)$ and black $\left(-50^{\circ} \mathrm{C}\right)$. Polynomial fits of first and third order are included for visibility. The transient evolution of the simulation of Fig. 5 is shown in green with circles spaced every $1000 \mathrm{yr}$ and ice initial temperature represented in color brightness as before. Ice thickness in northeastern Greenland responds rapidly to a reduction in total ice thickness, while ice in southern Greenland is more stable. 
melt layers have been found in the bottom section of Dye3 , which document a warm period with persistent ice during the last interglaciation (Dansgaard et al., 1985; Souchez et al., 1998). This has been confirmed by advanced dating technic providing direct evidence of ice predating the Eemian (Willerslev et al., 2007).

Note, however, that the existence of ice at Dye-3 and in southern Greenland during the last interglacial period does not preclude a considerable sea- level contribution from other sectors of the Greenland ice sheet. Unfortunately, there are no deep ice cores in northeastern Greenland. However, there are widespread marine deposits in this area from the last interglacial period, particularly during the period of peak warmth ( $123 \mathrm{ka}$; Funder, 1989; Mangerud and Funder, 1994; Alley et al., 2010). This indicates that seawater was present far inland following the penultimate glacial period, consistent with our model results. Marine conditions in northeastern Greenland (Kap Herschell) did not end until late in the last glacial cycle $(\sim 43 \mathrm{ka}$; Houmark-Nielsen et al., 1994). The long delay for the ice margin to re-advance to this site suggests that it retreated considerably during the Eemian. Note, however, that absolute dating on these records is relatively poor and generally limited to the identification of a warm period preceding the last glacial cycle.

Eemian ice was also found in the isolated ice cap on the Renland peninsula in eastern Greenland (Johnsen et al., 1992). A $20 \%$ increase in precipitation was reconstructed for the lowest $5 \mathrm{~m}$ of ice, as well as numerous melt layers. This is consistent with our interpretation that ice persisted due to high accumulation and despite the warmer climate and increased melting.

\section{Summary and conclusions}

The stability of different regions of the GrIS under Eemian climate has been investigated using a three-dimensional ice sheet model, a large ensemble of sensitivity experiments and detailed analysis of the regional imbalance between accumulation and ablation. The main finding is that the most vulnerable region in a warm climate, such as the last interglaciation, is northeastern Greenland because its dry climate with low accumulation can not compensate increased melting. This general finding is applicable to modern climate change. A second contributor to a negative mass balance for the northerm GrIS during the Eemian is the pronounced warming at high latitudes due to a meridional gradient in anomalous summer insolation. Although the physical mechanisms are different for modern climate change, enhanced warming at high latitudes (polar amplification) is a robust feature of climate projections. High volume loss in northern Greenland has also been found with a scenario of future climate warming (Stone et al., 2010).
An estimate on the contribution of ice sheets to sea-level rise is one of the most pressing needs for the assessment of future climate change (IPCC, 2007). The identification of key regions is a necessary requirement for which the Eemian, despite a different cause of warming, holds valuable information. A comparison of latitudinal sea surface and air temperature gradients based on proxy data from the Eemian with the projected greenhouse warming for the twenty-first century show a striking fit (Clark and Huybers, 2009), suggesting that the Greenland ice sheet might once again experience a sustained period with temperatures comparable to that of the last interglaciation, with its potential consequences for global sea level.

Recent trends in ablation must be interpreted with caution. Chylek et al. (2006) and Wake et al. (2009) show that negative surface mass balance anomalies in Greenland between 1995 and 2005 are not unprecedented in the last $140 \mathrm{yr}$, thus at least partly representing natural variability. Box et al. (2009) specify that while the warm period during the 1920s surpassed the annual average warming between 1994 and 2007, the latter period had warmer winters and a different regional distribution. The period of the 1920s and 1930s matches the modern surface mass balance (Fettweis et al., 2008; Wake et al., 2009) and a recent analysis of aerial imagery from the 1930s confirms that glacier retreat at the time was equally vigorous as in recent years (Bjørk et al., 2012). A notable difference between the modern and the 19231933 surface mass balance is the northeastern part of the GrIS, indicating that the recent increase in melting in this region might be a long-term trend. High current rates of mass loss in northeastern Greenland are also evident from detailed mass budget calculations (van den Broeke et al., 2009) and gravimetry (Chen et al., 2006; Ramillien et al., 2006).

Large melting areas on the southern GrIS and rapid thinning at its margins have raised concerns about the stability of these regions. However, it is conceivable that these observations represent the transient adjustment of the fastest reacting parts of the ice sheet, with highest mass turnover, to a relatively fast change in climate. These might mask slower processes that dominate the long-term fate of the GrIS and its contribution to sea-level rise. This study of the Eemian interglaciation demonstrates that a warmer climate over southern Greenland does not necessarily entail the disappearance of the southern dome.

Acknowledgements. We gratefully acknowledge Ralf Greve for public availability and comprehensive documentation of SICOPOLIS, Pascale Braconnot for providing data of IPSL CM4 as well as Bette Otto-Bliesner for data of CCSM3. Our work greatly benefited from discussions with Sigfús J. Johnsen and Bette L. Otto-Bliesner, as well as reviews of an early version of the manuscript by Shawn J. Marshall, Valérie Masson-Delmotte and three anonymous referees. ERA-40 data used in this study have been provided by the European Centre for Medium-Range Weather Forecasts. Greenland melt data based on passive microwave radiation was provided by 
the US National Snow and Ice Data Center. Computer time was provided by the Research Council of Norway through the NOTUR project. A.B. received support from the Marie Curie project NICE (MRTN-CT-2006-036127), the Swiss National Centre for Competence in Research "Climate", and the Marie Curie Intra-European Fellowship ECLIPS (PIEF-GA-2011-300544). This is publication no. A384 from the Bjerknes Centre for Climate Research.

Edited by: S. Marshall

\section{References}

Abdalati, W.: Greenland Ice Sheet Melt Characteristics Derived from Passive Microwave Data, Tech. rep., National Snow and Ice Data Center, Boulder, Colorado USA, 2007.

Alley, R. B., Andrews, J. T., Brigham-Grette, J., Clarke, G. K. C., Cuffey, K. M., Fitzpatrick, J. J., Funder, S., Marshall, S. J., Miller, G. H., Mitrovica, J. X., Muhs, D. R., Otto-Bliesner, B. L., Polyak, L., and White, J. W. C.: History of the Greenland Ice Sheet: paleoclimatic insights, Quaternary Sci. Rev., 29, 17281756, 2010.

Amante, C. and Eakins, B. W.: ETOPO1 1 Arc-Minute Global Relief Model: Procedures, Data Sources and Analysis, Tech. rep., NOAA Technical Memorandum NESDIS NGDC-24, 2009.

Applegate, P. J., Kirchner, N., Stone, E. J., Keller, K., and Greve, R.: Preliminary assessment of model parametric uncertainty in projections of Greenland Ice Sheet behavior, The Cryosphere Discuss., 5, 3175-3205, doi:10.5194/tcd-5-3175-2011, 2011.

Axford, Y., Briner, J. P., Francis, D. R., Miller, G. H., Walker, I. R., and Wolfe, A. P.: Chironomids record terrestrial temperature changes throughout Arctic interglacials of the past 200,000 yr, Geol. Soc. Am. Bull., 123, 1275-1287, 2011.

Bhattacharya, I., Jezek, K. C., Wang, L., and Liu, H.: Surface melt area variability of the Greenland ice sheet: 1979-2008, Geophys. Res. Lett., 36, L20502, doi:10.1029/2009GL039798, 2009.

Bjørk, A. A., Kjær, K. H., Korsgaard, N. J., Khan, S. A., Kjeldsen, K. K., Andresen, C. S., Box, J. E., Larsen, N. K., and Funder, S.: An aerial view of 80 years of climate-related glacier fluctuations in southeast Greenland, Nat. Geosci., 5, 427-432, doi:10.1038/ngeo1481, 2012.

Born, A., Nisancioglu, K. H., and Braconnot, P.: Sea ice induced changes in ocean circulation during the Eemian, Clim. Dynam., 35, 1361, doi:10.1007/s00382-009-0709-2, 2010.

Born, A., Nisancioglu, K. H., and Risebrobakken, B.: Late Eemian warming in the Nordic Seas as seen in proxy data and climate models, Paleoceanography, 26, PA2207, doi:10.1029/2010PA002027, 2011.

Box, J. E., Yang, L., Bromwich, D. H., and Bai, L.-S.: Greenland Ice Sheet Surface Air Temperature Variability: 1840-2007, J. Climate, 22, 4029-4049, 2009.

Braconnot, P., Marzin, C., Grégoire, L., Mosquet, E., and Marti, O.: Monsoon response to changes in Earth's orbital parameters: comparisons between simulations of the Eemian and of the Holocene, Clim. Past, 4, 281-294, doi:10.5194/cp-4-281-2008, 2008.

CAPE members: Last Interglacial Arctic warmth confirms polar amplification of climate change, Quaternary Sci. Rev., 25, 13831400, doi:10.1016/j.quascirev.2006.01.033, 2006.

Carlson, A., Stoner, J. S., Donnelly, J. P., and Hillaire-Marcel, C.: Response of the southern Greenland Ice Sheet during the last two deglaciations, Geology, 36, 359-362, 2008.

Chappellaz, J., Brook, E., Blunier, T., and Malaize, B.: $\mathrm{CH}_{4}$ and $\delta^{18} \mathrm{O}$ of $\mathrm{O}_{2}$ records from Antarctic and Greenland ice: a clue for stratigraphic disturbance in the bottom part of the GRIP and GISP2 ice-cores, J. Geophys. Res., 102, 26547-26557, 1997.

Chen, J. L., Wilson, C. R., and Tapley, B. D.: Satellite gravity measurements confirm accelerated melting of Greenland ice sheet, Science, 313, 1958-1960, 2006.

Christensen, J. H., Hewitson, B., Busuioc, A., Chen, A., Gao, X., Held, I., Jones, R., Kolli, R. K., Kwon, W.-T., Laprise, R., Magaña Rueda, V., Mearns, L., Menéndez, C. G., Räisänen, J., Rinke, A., Sarr, A., and Whetton, P.: Regional Climate Projections, in: Climate Change 2007: The Physical Science Basis, Contribution of Working Group I to the Fourth Assessment Report of the Intergovernmental Panel on Climate Change, edited by: Solomon, S., Qin, D., Manning, M., Chen, Z., Marquis, M., Averyt, K. B., Tignor, M., and Miller, H. L., Cambridge University Press, Cambridge, United Kingdom and New York, NY, USA, 2007.

Chylek, P., Dubey, M. K., and Lesins, G.: Greenland warming of 1920-1930 and 1995-2005, Geophys. Res. Lett., 33, L11707, doi:10.1029/2006GL026510, 2006.

Clark, P. U. and Huybers, P.: Interglacial and future sea level, Nature, 462, 856-857, 2009.

Colville, E. J., Carlson, A. E., Beard, B. L., Hatfield, R. G., Stoner, J. S., Reyes, A. V., and Ullman, D. J.: Sr-Nd-Pb Isotope Evidence for Ice-Sheet Presence on Southern Greenland During the Last Interglacial, Science, 333, 620-623, doi:10.1126/science.1204673, 2011.

Cuffey, K. M. and Marshall, S. J.: Substantial contribution to sea level rise during the last interglacial from the Greenland Ice Sheet, Nature, 404, 591-594, 2000.

Dahl-Jensen, D., Mosegaard, K., Gundestrup, N., Clow, G. D., Johnsen, S. J., Hansen, A. W., and Balling, N.: Past Temperatures Directly from the Greenland Ice Sheet, Science, 282, 268-271, 1998.

Dansgaard, W., Clausen, H., Gundestrup, N., Johnsen, S., and Rygner, C.: Dating and climatic interpretation of two deep Greenland ice cores, in: Greenland Ice Core: Geophysics, Geochemistry, and the Environment, edited by: Langway, C. C., Oeschger, H., and Dansgaard, W., 71-76, AGU Geophysical Monograph Series, No. 33, Washington, DC, 1985.

de Vernal, A. and Hillaire-Marcel, C.: Nature Variability of Greenland Climate Vegetation, and Ice Volume During the Past Million Years, Science, 320, 1622-1625, 2008.

Fettweis, X., Hanna, E., Gallée, H., Huybrechts, P., and Erpicum, M.: Estimation of the Greenland ice sheet surface mass balance for the 20th and 21st centuries, The Cryosphere, 2, 117-129, doi:10.5194/tc-2-117-2008, 2008.

Foresta, L.: An attempt of obtaining a chronologically correct reconstruction of the NEEM disturbed section, Master's thesis, 2011.

Funder, S.: Funder, S. Quaternary geology of the ice-free areas and adjacent shelves of Greenland, in: Quaternary Geology of Canada and Greenland, edited by: Fulton, R. J., 739-792, Geological Survey of Canada, Geology of Canada, 1989.

Fyke, J. G., Weaver, A. J., Pollard, D., Eby, M., Carter, L., and Mackintosh, A.: A new coupled ice sheet/climate model: description and sensitivity to model physics under Eemian, Last 
Glacial Maximum, late Holocene and modern climate conditions, Geosci. Model Dev., 4, 117-136, doi:10.5194/gmd-4-117$2011,2011$.

Greve, R.: A continuum-mechanical formulation for shallow polythermal ice sheets, Philos. T. R. Soc. Lond., 355, 921-974, 1997.

Hammer, C. U., Johnsen, S. J., Clausen, H. B., Dahl-Jensen, D., Gundestrup, N., and Steffensen, J. P.: The Paleoclimatic Record from a $345 \mathrm{~m}$ long Ice Core from the Hans Tausen Iskappe, Meddelelser om Grønland, Geoscience, 39, 87-95, 2001.

Houmark-Nielsen, M., Hansen, L., Jørgensen, M. E., and Kronborg, C.: Stratigraphy of a Late Pleistocene ice-cored moraine at Kap Herschell, Northeast Greenland, Boreas, 23, 505-512, doi:10.1111/j.1502-3885.1994.tb00618.x, 1994.

Huybrechts, P.: Sea-level changes at the LGM from ice-dynamic reconstructions of the Greenland and Antarctic ice sheets during the glacial cycles, Quaternary Sci. Rev., 21, 203-231, 2002.

IPCC: Climate Change 2007: The Physical Science Basis, Contribution of Working Group I to the Fourth Assessment Report of the Intergovernmental Panel on Climate Change, edited by: Solomon, S., Qin, D., Manning, M., Chen, Z., Marquis, M., Averyt, K. B., Tignor, M., and Miller, H. L., Cambridge University Press, Cambridge, United Kingdom and New York, NY, USA, 2007.

Jansen, E., Overpeck, J., Briffa, K., Duplessy, J.-C., Joos, F., Masson-Delmotte, V., Olago, D., Otto-Bliesner, B., Peltier, W., Rahmstorf, S., Ramesh, R., Raynaud, D., Rind, D., Solomina, O., Villalba, R., and Zhang, D.: Palaeoclimate, in: Climate Change 2007: The Physical Science Basis, Contribution of Working Group I to the Fourth Assessment Report of the Intergovernmental Panel on Climate Change, edited by: Solomon, S., Qin, D., Manning, M., Chen, Z., Marquis, M., Averyt, K. B., Tignor, M., and Miller, H. L., Cambridge University Press, Cambridge, United Kingdom and New York, NY, USA, 2007.

Johnsen, S. J., Clausen, H. B., Dansgaard, W., Gundestrup, N. S., Hansson, M., Jonsson, P., Steffensen, J. P., and Sveinbjørnsdottir, A. E.: A "deep" ice core from East Greenland, Meddelelser om Grønland, Geoscience, 29, 3-22, 1992.

Johnsen, S. J., Dahl-Jensen, D., Dansgaard, W., and Gudenstrup, N.: Greenland palaeotemperatures derived from GRIP bore hole temperature and ice core isotope profiles, Tellus B, 47, 624-629, 1995.

Koerner, R. M.: Ice Core Evidence for Extensive Melting of the Greenland Ice Sheet in the Last Interglacial, Science, 244, 964968, doi:10.1126/science.244.4907.964, 1989.

Kopp, R. E., Simons, F. J., Mitrovica, J. X., Maloof, A. C., and Oppenheimer, M.: Probabilistic assessment of sea level during the last interglacial stage, Nature, 467, 863-868, doi:10.1038/nature08686, 2009.

Landais, A., Steffensen, J. P., Caillon, N., Jouzel, J., MassonDelmotte, V., and Schwander, J.: Evidence for stratigraphic distortion in the Greenland Ice Core Project (GRIP) ice core during Event 5e1 (120 kyr BP) from gas isotopes, J. Geophys. Res., 109, D06103, doi:10.1029/2003JD004193, 2004.

Lemark, A.: A study of the Flade Isblink ice cap using a simple ice flow model, Master's thesis, Niels Bohr Institute, Copenhagen University, 2010.

Lhomme, N., Clarke, G. K. C., and Marshall, S. J.: Tracer transport in the Greenland Ice Sheet: constraints on ice cores and glacial history, Quaternary Sci. Rev., 24, 173-194, 2005.
Loutre, M.-F., Paillard, D., Vimeux, F., and Cortijo, E.: Does mean annual insolation have the potential to change the climate?, Earth Planet. Sc. Lett., 221, 1-14, 2004.

Lüthi, D., Floch, M. L., Bereiter, B., Blunier, T., Barnola, J.-M., Siegenthaler, U., Raynaud, D., Jouzel, J., Fischer, H., Kawamura, K., and Stocker, T.: High-resolution carbon dioxide concentration record 650,000-800,000 years before present, Nature, 453, 379-382, 2008.

Mangerud, J. and Funder, S.: The interglacial-glacial record at the mouth of Scoresby Sund, East Greenland, Boreas, 23, 349-358, 1994.

Marti, O., Braconnot, P., Bellier, J., Benshila, R., Bony, S., Brockmann, P., Cadule, P., Caubel, A., Denvil, S., Dufresne, J.-L., Fairhead, L., Filiberti, M.-A., Foujols, M.-A., Fichefet, T., Friedlingstein, P., Gosse, H., Grandpeix, J.-Y., Hourdin, F., Krinner, G., Lévy, C., Madec, G., Musat, I., de Noblet, N., Polcher, J., and Talandier, C.: The new IPSL climate system model: IPSL-CM4, Tech. rep., IPSL Global Climate Modeling Group, 2005.

Masson-Delmotte, V., Stenni, B., Pol, K., Braconnot, P., Cattani, O., Falourd, S., Kageyama, M., Jouzel, J., Landais, A., Minster, B., Barnola, J., Chappellaz, J., Krinner, G., Johnsen, S., Röthlisberger, R., Hansen, J., Mikolajewicz, U., and Otto-Bliesner, B.: EPICA Dome C record of glacial and interglacial intensities, Quaternary Sci. Rev., 29, 113-128, doi:10.1016/j.quascirev.2009.09.030, 2010.

Masson-Delmotte, V., Braconnot, P., Hoffmann, G., Jouzel, J., Kageyama, M., Landais, A., Lejeune, Q., Risi, C., Sime, L., Sjolte, J., Swingedouw, D., and Vinther, B.: Sensitivity of interglacial Greenland temperature and $\delta^{18} \mathrm{O}$ : ice core data, orbital and increased $\mathrm{CO}_{2}$ climate simulations, Clim. Past, 7, 10411059, doi:10.5194/cp-7-1041-2011, 2011.

McKay, N. P., Overpeck, J. T., and Otto-Bliesner, B. L.: The role of ocean thermal expansion in Last Interglacial sea level rise, Geophys. Res. Lett., 38, L14605, doi:10.1029/2011GL048280, 2011.

NGRIP-members: High-resolution record of Norhtern Hemisphere climate extending into the last interglacial period, Nature, 431, 147-151, 2004.

Oerlemans, J., Dahl-Jensen, D., and Masson-Delmotte, V.: Ice sheets and sea level, Science, 313, 1043-1045, 2006.

Otto-Bliesner, B. L., Marshall, S. J., Overpeck, J. T., Miller, G. H., $\mathrm{Hu}, \mathrm{A}$., and CAPE Last Interglacial Project members: Simulating Arctic Climate Warmth and Icefield Retreat in the Last Interglaciation, Science, 311, 1751-1753, 2006.

Overpeck, J. T., Otto-Bliesner, B. L., Miller, G. H., Muhs, D. R., Alley, R. B., and Kiehl, J. T.: Paleoclimatic Evidence for Future IceSheet Instability and Rapid Sea-Level Rise, Science, 311, 17471750, 2006.

Petit, J. R., Jouzel, J., Raynaud, D., Barkov, N. I., Barnola, J.-M., Basile, I., Bender, M., Chappellaz, J., Davisk, M., Delaygue, G., Delmotte, M., Kotlyakov, V. M., Legrand, M., Lipenkov, V. Y., Lorius, C., Pin, L. P., Ritz, C., Saltzmank, E., and Stievenard, M.: Climate and atmospheric history of the past 420,000 years from the Vostok ice core, Antarctica, Nature, 399, 429-436, 1999.

Pollack, H. N., Hurter, S. J., and Johnson, J. R.: Heat flow from the Earth's interior: analysis of the global data set, Rev. Geophys., 31, 267-280, 1993.

Pritchard, H. D., Arthern, R. J., Vaughan, D. G., and Edwards, L. A.: Extensive dynamic thinning on the margins of the 
Greenland and Antarctic ice sheets, Nature, 461, 971-975, doi:10.1038/nature08471, 2009.

Ramillien, G., Lombard, A., Cazenave, A., Ivins, E. R., Llubes, M., Remy, F., and Biancale, R.: Interannual variations of the mass balance of the Antarctica and Greenland ice sheets from GRACE, Global Planet. Change, 53, 198-208, doi:10.1016/j.gloplacha.2006.06.003, 2006.

Raynaud, D., Chappellaz, J., Ritz, C., and Martinerie, P.: Air content along the GRIP core: a record of surface climatic parameters and elevation in Central Greeland, J. Geophys. Res., 102, $26607-$ 26613, 1997.

Reeh, N.: Parameterization of melt rate and surface temperature on the Greenland Ice Sheet, Polarforschung, 59, 113-128, 1991.

Rignot, E., Velicogna, I., van den Broeke, M. R., Monaghan, A., and Lenaerts, J.: Acceleration of the contribution of the Greenland and Antarctic ice sheets to sea level rise, Geophys. Res. Lett., 38, L05503, doi:10.1029/2011GL046583, 2011.

Ritz, C., Fabre, A., and Letréguilly, A.: Sensitivity of a Greenland ice sheet model to ice flow and ablation parameters: consequences for the evolution through the last climatic cycle, Clim. Dynam., 13, 11-24, 1997.

Robinson, A., Calov, R., and Ganopolski, A.: Greenland ice sheet model parameters constrained using simulations of the Eemian Interglacial, Clim. Past, 7, 381-396, doi:10.5194/cp-7-381-2011, 2011.

Souchez, R., Bouzette, A., Clausen, H. B., Johnsen, S. J., and Jouzel, J.: A stacked mixing sequence at the base of the Dye 3 core, Greenland, Geophys. Res. Lett., 25, 1943-1946, 1998.

Steffen, K. and Box, J.: Surface climatology of the Greenland ice sheet: Greenland Climate Network 1995-1999, J. Geophys. Res., 106, 33951-33964, 2001.

Stone, E. J., Lunt, D. J., Rutt, I. C., and Hanna, E.: Investigating the sensitivity of numerical model simulations of the modern state of the Greenland ice-sheet and its future response to climate change, The Cryosphere, 4, 397-417, doi:10.5194/tc-4-397-2010, 2010.

Suwa, M., von Fischer, J. C., Bender, M. L., Landais, A., and Brook, E. J.: The Last Interglacial climate in Greenland inferred from the disturbed bottom section of the GISP2 and the GRIP ice cores, J. Geophys. Res., 111, D02101, doi:10.1029/2005JD006032, 2006.
Svensson, A., Bigler, M., Kettner, E., Dahl-Jensen, D., Johnsen, S., Kipfstuhl, S., Nielsen, M., and Steffensen, J. P.: Annual layering in the NGRIP ice core during the Eemian, Clim. Past, 7, 1427 1437, doi:10.5194/cp-7-1427-2011, 2011.

Tarasov, L. and Peltier, W. R.: Greenland glacial history, borehole constraints, and Eemian extend, J. Geophys. Res., 108, 2143, doi:10.1029/2001JB001731, 2003.

van de Berg, W. J., van den Broeke, M., Ettema, J., van Meijgaard, E., and Kaspar, F.: Significant contribution of insolation to Eemian melting of the Greenland ice sheet, Nat. Geosci., 4, 679-683, 2011.

van den Broeke, M., Bamber, J., Ettema, J., Rignot, E., Schrama, E., van de Berg, W. J., van Meijgaard, E., Velicogna, I., and Wouters, B.: Partitioning Recent Greenland Mass Loss, Science, 326, 984 986, 2009.

Velicogna, I.: Increasing rates of ice mass loss from the Greenland and Antarctic ice sheets revealed by GRACE, Geophys. Res. Lett., 36, L19503, doi:10.1029/2009GL040222, 2009.

Wake, L. M., Huybrechts, P., Box, J. E., Hanna, E., Janssens, I., and Milne, G. A.: Surface mass-balance changes of the Greenland ice sheet since 1866, Ann. Glaciol., 50, 178-184, 2009.

Willerslev, E., Cappellini, E., Boomsma, W., Nielsen, R., Hebsgaard, M. B., Brand, T. B., Hofreiter, M., Bunce, M., Poinar, H. N., Dahl-Jensen, D., Johnsen, S., Steffensen, J. P., Bennike, O., Schwenninger, J.-L., Nathan, R., Armitage, S., de Hoog, C.J., Alfimov, V., Christl, M., Beer, J., Muscheler, R., Barker, J., Sharp, M., Penkman, K. E., Haile, J., Taberlet, P., Thomas, M., Gilbert, P., Casoli, A., Campani, E., and Collins, M. J.: Ancient Biomolecules from Deep Ice Cores Reveal a Forested Southern Greenland, Science, 317, 111-114, 2007.

Yokoyama, Y. and Esat, T. M.: Global climate and sea level: Enduring variability and rapid fluctuations over the past 150,000 years, Oceanography, 24, 54-69, doi:10.5670/oceanog.2011.27, 2011. 